\title{
INSTITUTIONALISING CHINESENESS: LEGACIES OF CHINESE COMMERCIAL HEGEMONY IN THE CAMBODIAN SILK INDUSTRY
}

\author{
Heidi Dahles (corresponding author) \\ Department of Organization Sciences, VU University Amsterdam, De Boelelaan 1081, \\ Amsterdam, The Netherlands.
}

Email: h.dahles@vu.nl

and

\section{John ter Horst}

Windesheim University of Applied Sciences, Campus 2-6, Zwolle, The Netherlands.

Email: johnterhorst2@ hotmail.com

\begin{abstract}
The Cambodian silk weaving industry shows a remarkable pattern of ethnicised positions interlocked in processes of production and trade stretching beyond Cambodia into the Southeast Asian region and into Europe and the United States. Key commercial positions in the Cambodian silk trading networks are dominated by the Chinese, at least so it seems. In contrast to the bulk of literature on Chinese capitalism, the current study addresses a situation in which the commercial positions are identified as Chinese regardless of the ethnic background of the people who occupy them. While subscribing to the institutional perspective on Chinese capitalism, this article aims to take the debate one step further by arguing that - while a particular institutional embedding is conducive to Chinese proliferation in the business sector - Chinese business practices and representations are themselves subject to processes of institutionalisation. The paper explains how they may develop into an institution that is both a model of and for conducting business.
\end{abstract}

KEY WORDS: Cambodian Chinese, silk industry, Chinese capitalism, institutional legacies, ethnicisation

The Chinese presence in Cambodian towns and cities is ubiquitous. In major cities like Phnom Penh, Siem Reap and Battambang, entrepreneurs and business people decorate their house-fronts and interiors with Chinese characters, lanterns, shrines and other Chinese paraphernalia. These expressions of "Chineseness" seem to have proliferated during the last decade representing both continuity and change in the position of the ethnic Chinese in Cambodia. The current Sinification process in Cambodia seems to reflect developments in Southeast Asia at large where the persistent economic dominance of the Chinese has been paralleled by a lack of political power and - in some cases - restricted articulations of Chinese identity (e.g. Gomez, 2002; Gomez and Hsiao, 2004; Suryadinata, 1997; Menkhoff 
and Gerke, 2002). While the Cambodian case resembles many other Southeast Asian countries in terms of Chinese economic dominance, there are also differences pertaining in particular to the degree of integration of the Chinese in national and local society.

Comparative studies emphasise that in mainland Southeast Asia Chinese immigrants blended into local society more easily and completely than in insular Southeast Asia due to divergent migration histories (Kuhn, 2006: 77-78).

The Angkor kingdom (800-1400AD) and its successors have been viewed as "plural societies," held together by economic specialisation between different ethnic groups (Willmott, 1967, 1970). As ethnic and economic boundaries coincided, competition for scarce resources between the Khmer and Chinese were missing and, therefore, inter-ethnic relations were based on mutual concurrence (Willmott, 1970: 8).This "plural society" came under pressure when - at the end of the $19^{\text {th }}$ century - the establishment of the French protectorate unleashed processes of change in the relationship between Khmer and Chinese which irreversibly distinguished the Chinese as an ethnic minority - a position which was absent in pre-colonial society and marked the onset of a century of discriminatory measures. After independence in 1953 the once symbiotic relationship between the Chinese and the Khmer - burdened with this colonial legacy - declined, culminating in the total eclipse of Chinese business and identity under the Pol Pot regime (1975-79). The various and diverse Cambodian governments after1979 assumed discriminatory policies towards the ethnic Chinese which lasted into the early 1990s. While the Cambodian economy continued to depend on private Chinese enterprises, the Chinese became invisible in Cambodian public life (Gottesman, 2004: 179, 189). The current re-emergence of the ethnic Chinese in the urban business districts, however, seems to indicate not only the revitalisation of Chinese identity, but also the restoration of the plural society in which business and trade were purely 
Chinese affairs and Chinese "thrift and industry" represented a model for financial success (Edwards, 2007: 221).

The revitalisation of the Cambodian silk weaving industry after the Pol Pot era is a case in point exemplifying the ways in which the "Chinese model" for business success became re-established in Cambodian society. The current silk industry builds on legacies that reach back into the 14th century when Chinese merchants and, in their wake, the revenue farm system for the production of silk took root in the Angkor kingdom. Throughout colonial times and into the 1960s the Chinese played a crucial role in the organisation of the silk production and trade in Cambodia. After its eclipse during the 1970s, silk weaving was resumed in a number of villages in the vicinity of Phnom Penh during the 1980s to develop into a significant industry in the 1990s. Today, silk is worn at ceremonial occasions both by royalty and commoners. However, the the bulk of silk products is purchased by international tourists visiting Cambodia, foreign professionals working for the many donor agencies and, increasingly, former refugees who return to Cambodia temporarily for family visits and acquire silk to resell in their host-countries (Dahles and Zwart, 2003).

The Cambodian silk industry shows a remarkable pattern of ethnicised positions interlocked in processes of production and trade stretching beyond Cambodia into the Southeast Asian region and into Europe and the United States. Key positions in the organisation of the silk industry are dominated again by the Chinese, at least so it seems. Strikingly, the individuals that are moving into the commercial positions in the silk industry assume the identity markers that come with the position. In contrast to the bulk of literature on the ethnic Chinese in Southeast Asia where ethnic Chinese usually dominate in commercial positions, the current study addresses a situation in which the commercial positions are identified as Chinese regardless of the ethnic background of the people who occupy them. As will be shown in interviews below, the silk traders and wholesalers cultivate 
a self-presentation that identifies them as Chinese. They are denoted as cen - literally "Chinese" but also the term used for commercial professions. Cen lead urban lives, dress in "Chinese" fashion, decorate their shops and homes with "Chinese" paraphernalia, celebrate Chinese New Year and engage in gift giving and credit paying. ${ }^{1}$ Silk weavers, on the other hand, lead rural lives, wear Khmer attire and observe Khmer holidays. If such a weaver is promoted to the position of trader or wholesaler, she becomes cen and assumes "Chinese" patterns of behaviour and expressions of self-identity. These Khmer and Chinese selfpresentations, one may argue, have to be viewed not as primordial affiliations or stateorchestrated ethnic arrangements, but instead as institutions rooted in the multilayered legacies of ethnic relations in Cambodia.

This article addresses the question as to how these multilayered legacies contributed to the establishment of the cen as an economic institution in Cambodian society. Empirically, this article deals with the role of institutional legacies in the ways in which the Chinese took and maintained control of key positions in the Cambodian silk industry. Theoretically, this article aims at contributing to the ongoing debate on "Chinese capitalism" or the striking congruence between the prominent Chinese presence and alleged success in the business sector. While subscribing to the institutional perspective on Chinese capitalism, this article aims to take the debate one step further. It will be argued that, while a particular institutional embedding is conducive to Chinese proliferation in the business sector, Chinese business practices and representations are themselves subject to processes of institutionalisation. As will be explained below, these practices and presentations may develop into an institution that is both a model of and a model for conducting business.

The empirical data on which this article is based are derived from the second author's dissertation research which focused on processes of negotiation and enactment of Khmer and Chinese identities in the Cambodian silk industry (Ter Horst, 2008). The research revolved 
around the mapping of networks constituting the Cambodian silk industry and the situational nature of ethnic self-representations among the actors involved in these networks. In the light of the explorative character of the research and its focus on sense-making, ethnographic fieldwork was the major methodology applied. This methodology offers an understanding of the social construction of meaning and interpretations "from within and from below" (see Hammersley and Atkinson, 1995). Moreover, this methodology is well suited for situations in which no direct questioning on sensitive matters is possible as is the case with ethnic origin in Cambodia (see Edwards, 2009: 177).

This article is structured as follows. The next section offers a theoretical exploration of the institutional perspective on Chinese capitalism. The main body of the article consists of a description of the history and the current ethnicised organisation of the silk industry. The analytical section reconnects this ethnicised organisation with the institutional legacies of Chinese commercial hegemony in Cambodia. The article concludes with a brief outlook on the theoretical contribution of this article.

\section{THE INSTITUTIONALISATION OF CHINESENESS: A THEORETICAL EXPLORATION}

In the 1990s, scholars of diverse disciplinary backgrounds involving themselves with the study of Asian economies and societies attempted to find plausible explanations for the spectacular rise of the "Tiger Economies" of East and Southeast Asia. Among the multitude of explanations produced to address the "Asian Miracle," a prominent role was assigned by some scholars to the business practices of the ethnic Chinese minority groups residing in these countries (cf. Chan, 2000; Gomez and Hsiao, 2004; Menkhoff and Gerke, 2002; Weidenbaum and Hughes, 1996). The ethnic Chinese were viewed as endowed with 
exceptional entrepreneurial zest which - according to some scholars and business analysts was rooted in Confucian culture that the ethnic Chinese brought along when migrating from China to Southeast Asia (Fukuyama, 1995; Kotkin, 1993; Redding, 1990; Weidenbaum and Hughes, 1996). Hence, the image of the networking, family-based, guanxi-driven, ${ }^{2}$ flexible, ethnic Chinese business has become a trope in the literature on transnational relations in contemporary Southeast Asia. Ethnic Chinese networks have been the spearheads of Asia's economic growth, as well as a major global force. Coupled with the capacity for hard work and trust based on blood ties and personal relations, these networks seem to distinguish "Chinese capitalism" from Western capitalism and seem to have engendered economic success where others have failed (Redding, 1990).

However, as critics have pointed out, the homogenising assumptions of this so-called culturalist approach to Chinese capitalism ignore the experiences of Chinese communities and individual Chinese entrepreneurs under specific and widely differing economic and political conditions in the region (Suryadinata, 1997). By focusing entirely on the ways in which ethnic identity shapes, even determines, economic practices and social life, the culturalist approach has come to essentialise ethnic identity and contribute to the "othering" of the Chinese as "perpetual outsiders" (see Chang, 2003). Conversely, the "instrumentalist" approach deconstructs this image and focuses on how specific global, national and local economic arrangements present Chinese with business opportunities. Mutual interest, instead of a common ethnic identity, seems to characterise successful co-operative efforts among Chinese businesses within and across national borders (Gomez, 2002; Gomez and Hsiao, 2004). Instrumentalist approaches to Chinese capitalism emphasise the accommodating character of business strategies among ethnic Chinese, in particular the conditions under which business deals are generated, negotiations are conducted, and co-operative ventures are settled (Gomez, 1999; Jesudason, 1989). 
In this "culture versus instrumentalism" debate little attention has been paid to the role of institutional actors and structures shaping Chinese business activities in time and space. The institutional approach to Chinese capitalism addresses the actor-structure relationship in its situational and contextual framework. Before elaborating this particular approach, a few words about the concept of institution are in order here. Institutions are generally defined as "systems of established and prevalent social rules that structure social interactions" (Hodgson, 2006: 2), including social conventions (Searle, 1995). Institutions are characterised by a high degree of resilience which imposes constraints on human action that at the same time can open up new opportunities. Institutions are perpetuated because they represent accepted models of conduct while, at the same time, these models offer compelling guidelines for proper behaviour and practice. Whereas individual actors are born and raised within pre-existing institutions which "reside in the dispositions of other individuals" (Hodgson, 2006: 8), it is human agency that enacts these institutions and thereby both perpetuates and changes them. Despite their resilience, institutions are subject to processes of change "both incremental and discontinuous" (Scott, 2001: 48).

In order to capture the simultaneously constraining and enabling impact of institutions on human action, institutional scholars introduced the concept of embeddedness (Granovetter, 1985; Zukin and DiMaggio, 1990). It has been argued that embedded economic activities such as in family-based businesses, trust-based reciprocal relationships, personalised or business networks, and business communities are useful institutional means of implementing co-operative strategies within and across national borders (Yeung and Olds, 2000: 15).

Turning to ethnic Chinese businesses, embeddedness is provided by participation in business networks and communities, high levels of personal and social interaction among actors in these networks, collective representation through trade and commercial associations and informal business groupings, and patronage relationships with people in power (Yeung and 
Olds, 2000: 15-16; Hamilton, 1991; 1996; 2000). Ethnic Chinese businesspeople accumulate social capital by maintaining membership in a number of partly overlapping networks which enables them to evade failing vertical linkages. Guanxi-based trust is an expansive and inclusive principle contributing to the "institutional thickness" that characterises ethnic Chinese business networks in a globalising business environment (see Chan and Tong, 2000: 74; Tan and Yeung, 2000: 240). Such networks may comprehend ties with officials in institutional environments conducive to Chinese business, but they may also exclude such linkages and enable ethnic Chinese businesspeople to operate despite bureaucratic obstacles. The institutional perspective contests essentialist arguments that culture, ethnic identities and value systems determine ethnic business activities. Instead, culture and ethnicity are viewed as abstractions of institutions that can be manipulated by governments, businesspeople and community organisations in the pursuit of their own goals.

A historical perspective enables scholars to understand the emergence and perpetuation of institutions, as "[h]istory provides the resources and constraints, in each case both material and cognitive, in which we think, act, and create" (Hodgson, 2006: 8). The concept of "institutional legacies" addresses societal transformations as a function of the social, cultural, and institutional structures created under past regimes that persist in the present period. In this view the "past casts a long shadow on the present, shapes the environment in which the battle to define and defend new institutions takes place ..." (Crawford and Lijphart, 1997: 2). Proponents of this approach argue that dominant social, cultural, and political forces at work in the larger society are rooted in power struggles that evolved throughout history and currently shape the identity of new institutions (Crawford and Lijphart, 1997: 9). In order to capture the dynamics of such processes, individual and collective actors have to be viewed not in terms of passive recipients of institutional resources "but as actors involved in both the construction and reconstruction of such resources within 
and across national contexts" (Morgan and Quack, 2005: 1765). Individual and collective actors that cross national borders have to deal with increasing diversity in both their organisational practice and institutional environment and may draw "on 'sleeping' nearly forgotten institutional legacies as a resource for their institutional change projects"(Morgan and Quack, 2005: 1765).

Turning to the institutional legacies of the ethnic Chinese in Southeast Asia, the legendary entrepreneurial spirit of the ethnic Chinese is not a "given" cultural trait but an adaptation to life in the colonial and post-colonial economies where they were allocated positions that furthered the interests of the ruling elite - indigenous, colonial and national alike (Wee and Chan, 2006; Wee, Jacobsen and Tiong, 2006). As McVey (1992: 18) points out, the economic role of the ethnic Chinese in Southeast Asia is relatively recent and has been determined by historical-political factors, which had little to do with Chinese culture per se. In the $19^{\text {th }}$ and early $20^{\text {th }}$ centuries - due to population pressure, political unrest and poverty - many Chinese left their home in the coastal provinces of southern China to make a living in parts of Southeast Asia. The vast majority of these poor peasant immigrants - often arriving indebted for the payment of their passage and denied access to land -became indentured or wage labourers in the Southeast Asian colonial economies. Only a tiny minority of the Chinese, many of whom with higher status and established before the poor masses arrived acted as merchants, traders, shopkeepers, tax collectors or moneylenders. However, it was this minority that came to dominate images of the "overseas Chinese" (Cohen, 1997; Kuhn, 2006). This collective historical background generated discourses of the sojourner, the diasporic entrepreneur, the comprador, tax-farmer and middleman. However divergent, these positions imply limited opportunities for upward mobility as much as fresh openings stemming from new economic niches and capital accumulation. As one's livelihood is easily jeopardised in such a situation, the reliance on institutions such as family support, 
reciprocal ties, networks and patronage relations attain crucial importance for risk reduction, economic consolidation and entrepreneurial venturing.

So far, the institutional perspective provides an understanding of the emergence, development and perpetuation of ethnic Chinese commercial activities in colonial and postcolonial Southeast Asia. However, the institutional approach has not yet addressed the disembedding of Chinese business practices from the ethnic Chinese community and its abstraction as a model for doing business in general. This article suggests that ethnic Chinese ways of doing business are becoming subject to processes of institutionalisation. In social theory the concept of institutionalisation refers to processes of social embedding within an organisation, system, or society as a whole (Scott, 2001: 15). Tomlinson (2003: 272), following Giddens (1990), argues that modernity in particular facilitates the "abstraction of social and cultural practices from contexts of local particularity, and their institutionalisation and regulation across time and space." While Tomlinson positions such processes of institutionalisation predominantly in the domain of "cultural identity," institutional and organisational scholars observe that such processes also transpire in the organisational and business domain (e.g. Hatch and Schultz, 2004). People "live" their occupational, professional and corporate identities as much as they live their gender, ethnicity and nationality "as publicly institutionalized, discursively organized belongings" (Tomlinson, 2003: 273). As the remainder of this article will show, an institutional perspective on Chinese businesses in the Cambodian silk industry reveals the ways in which both long-standing and newly created institutional legacies are strategically employed, abandoned, even silenced and again revitalised under rapidly changing and ambivalent institutional regimes to culminate in the institutionalisation of Chineseness.

\section{THE CAMBODIAN SILK INDUSTRY: A VERY BRIEF HISTORY}


There is only scant evidence about the origins of Cambodian silk weaving. Comparing traditional Indian attire with Khmer costumes on the Angkorean bass reliefs, textile experts argue that the Khmer ruling class of the $9^{\text {th }}$ to $14^{\text {th }}$ century adopted weaving techniques and finished products from India, Siam, and from South and Southwest China (Green, 2003, 2004; Howard, 1999; Larsen, 1979). In the "Age of Commerce" (1450-1680), with the arrival of the Chinese Ming fleets and its traders maintaining regular trade relations between China and mainland Southeast Asia the Cambodian kings moved the kingdom's capital city from inland Angkor to riverine Phnom Penh (Vickery, 2004), which emerged as one of the flourishing port cities of South East Asia (Reid, 1993: 32). Phnom Penh rapidly developed into one of the centres of Indochinese textile trade (Edwards, 2003: 16). Here, as in many other cities in Southeast Asia, the Chinese came to constitute the commercially most active ethnic group (Igout, 1993: 5-6; Willmott, 1967: 28).

In the mid-eighteenth century the southern Chinese districts of Shunde, Nanhai and Hsiangshan in the Pearl River delta were by far the largest silk producing regions in China (So, 1986). By the $19^{\text {th }}$ century livelihoods in Southern China declined as a consequence of political and economic turbulence that led to an exodus of population. These exiles, among whom many Cantonese silk merchants, landowning gentry, and silk producers, often followed in the footsteps of earlier trade and migration flows (Kuhn, 2006; Miles, 2006). The Shunde County silk producers established mulberry plots along the rivers of Tonle Sap, Mekong and Bassac where they found the fertile ground for mulberry cultivation similar to their home county (So, 1986: 18-19).

Cantonese silk merchants played a prominent role in the establishment of a silk industry in the riverine lowlands, investing in mulberry ventures and transplanting their silk enterprises to Cambodia. These Cantonese merchants encountered no indigenous competition 
as they established their silk ventures in Cambodia. They organised the silk production locally by leasing thousands of hectares of mulberry plots from local peasants and involving thousands of rural households in the rearing of silk worms, spinning silk yarn and weaving silk fabrics (So 1986: 85-88). At the same time, the Khmer kings entrusted Chinese merchants with both local and maritime trade. The kings - understanding that the Chinese brought wealth to their kingdom while seemingly not posing any political threat (Kuhn, 2006: 10) - leased lucrative revenue farms for opium and fishing to these merchants who established themselves in the kingdom as entrepreneurs, middlemen, tax-farmers and moneylenders (Willmott, 1967: 45).

After the French had established a Protectorate over Cambodia in 1863 the possibilities of sericulture were investigated by colonial officials (see Henry, 1932; de Campocasso, 1923). When exploring the Southern parts of Indochina, these officials observed an already flourishing silk industry along the banks of the Tonle Sap and the Bassac and Mekong rivers. The French were confident that the local silk producers constituted a potential workforce in their future silk ventures and French planters moved to Indochina to set up mulberry plantations (Frederico, 1997: 166-7). The procurement of Chinese silk yarn was of crucial importance to the French silk industry which had been hit by a disease called pebrine, which had ravaged the livelihoods of some 70,000 silk farmers in Lyon (Frederico, 1997: 30). No cure could not be found for this disease, and the only way to minimise the impact for the French silk producers was to buy silk worm eggs from unaffected areas.

However, these French entrepreneurs met with the vested interests of the Chinese merchants who controlled much of the available rural labour force. The French company that organised the colonial silk trade, La Compagnie De Soie du Cambodge et de la Cochinchine did not possess large mulberry plantations itself, but depended on some 1,000 private plots spread over 235 villages in Cambodia and Cochinchina (Henry, 1932: 400). As a 
consequence La Compagnie had to contract Cantonese traders to collect the silk yarn from rural villages and to transport the yarn to Phnom Penh for shipment to France. These Chinese traders, however, played multiple roles, as they were often co-villagers and moneylenders of the rural silk spinners working for the French and, at the same time, members of the same dialect group as the Cantonese merchants and owners of silk spinneries in Phnom Penh (Forest, 1980: 304).

In the early twentieth century, Chinese business was increasingly affected by restrictive colonial measures. A new taxation regime prohibited the Chinese from owning land or practicing a number of professions, and abolished tax farms (Willmott, 1967). These measures forced the Chinese in Cambodia to revise their economic strategies. With mulberry plantations passing into French hands, the Chinese became subcontractors of the new owners organising the coolie labour and trade in raw silk (Henry, 1932: 400). However, Cambodian sericulture was seriously affected by a worldwide fall of silk cocoon prices in the 1920 s. Coupled with the economic effects of the Great Depression, this "silk crisis" led to the collapse of the Cambodian silk industry, causing the bankruptcy of many French planters and mill owners. As a consequence, many Cantonese merchants had to give up their involvement in the silk industry and returned to China (Robequain, 1944: 43)., When World War II swept across Europe and the Pacific disrupting the naval trade connections with France and all major Asian entrepôts, the Cambodian economy fell into a serious crisis characterised by serious food shortages and extreme poverty (Muan and Daravuth, 2003: 8).

Following World War II the silk weaving industry underwent a revitalisation as the silk woven sampot hol - an ikat woven skirt, worn like a sarong - became a symbol of the struggle for Cambodian independence and of national identity (see Edwards, 2001). While the Chinese-dominated silk industry had been destroyed, Cambodian peasants resumed work at their handlooms, keeping up small-scale production for domestic use and for the modest 
flow of tourists visiting the Angkor temple complex (see Delvert, 1961: 282-4). Agricultural communities in the river basins engaged in small-scale handloom silk weaving during slack periods in the agricultural cycle. The weavers - the majority of whom were females - sold their products at provincial markets. However, with the end of the colonial regime in 1953 and the friendly relations established between Cambodia and China during the 1955 Bandung Conference, Cantonese silk merchants again set up silk spinning factories at the outskirts of Phnom Penh and provided rural silk weavers with raw silk from China, Japan and Vietnam (Ter Horst, 2008: 112-113). Sericulture was not revived as the Chinese - due to a colonial legacy - were not permitted to own or lease land in post-colonial Cambodia.

In the 1960s the Cambodian agricultural sector underwent far-reaching reform by establishing Khmer farmers' co-operatives and the nationalisation of large parts of the Cambodian economy, in particular the lucrative import and export businesses which were largely in Sino-Cambodian hands. These measures undercut Chinese commercial activities and affected the ailing silk industry which depended on Chinese middlemen trading raw silk within and across the Cambodian border. In 1970 General Lon Nol mounted a coup d'état that ushered a decade of bitter political struggle involving Cambodia in the Indochina War and culminating in the gruesome Pol Pot regime (1975-79). During this period, all commercial activities, including silk production and trade, came to a halt (see Kiernan, 1986). But soon after the Vietnamese invasion drove the Khmer Rouge to the border areas and established some measure of order in the country, Chinese business people resurfacing from hide-outs in the countryside or returning from refugee camps or foreign countries resumed their trade activities, including the import of raw silk from the Vietnamese Tan Chau spinneries. With silk yarn trickling in, the rural weavers returned to their hand looms. In the 1980s some 5,000 looms were clacking again (Pujebet and Peyre, 2001), while traders from rural towns such as Poipet, Pursat and Battambang came to Phnom Penh to exchange Thai 
and Lao handicrafts for silk woven products (Ter Horst, 2008: 116). The hand-woven silk found its way into refugee camps on the Thailand border, and from there, through the hands of returnee aid workers, into the overseas Cambodian exile communities (Ter Horst, 2008: 118). With the first weavers at the loom, Chinese traders crossing borders and a market developing, the Cambodian silk industry was re-established, as the next section will show.

\section{ORGANISING THE SILK INDUSTRY}

As the previous section has shown, the Cambodian silk industry has been integrated in multi-layered transnational business networks for a long time. Currently, these networks comprise silkworm rearing farms and silk yarn producing factories in the Vietnamese borderlands, Cambodian silk weaving communities, urban-based wholesalers and retailers, middlemen provisioning of weavers with yarn and credit, and sampot wearing and silk retailing Cambodian exiles in Paris, Lyon or Long Beach. Silk threads connecting producers, traders and consumers across borders and continents are knotted together by institutions organising and regulating the silk industry. In contemporary Cambodia, current national demand for silk yarn is about 400 tons per year, less than five tons of which is met by local production with the rest being imported from China and Vietnam (Marks, 2010). This means that silk weaving constitutes only a tiny sector of a much larger garment industry (see Rasiah, 2009; Arnold and Toh, 2010).

In the silk industry, the relationships between weavers, wholesalers, middlemen and retailers are organised according to hierarchical and ethnic principles. This section will discuss the organisation of the current Cambodian silk industry from the perspective of its major actors and will identify the ways in which Chinese identity intervenes in this organisation. 


\section{The Weavers}

In present-day Cambodia, silk weaving occurs in the riverine rural areas, but shows the largest concentrations in four craft communities situated on the banks of the rivers Mekong and Bassac and the Tonle Sap, in the lower Mekong Delta. Most of these silk weavers are descendants of silk cultivators from Southern China who intermarried with Khmer people, assumed Cambodian citizenship and, often, a Khmer identity. However, some of them remember their Chinese background and keep a few mementos of their family heritage (see Ter Horst, 2008: 17-20). Pheach Tot (aged 77) a silk weaver from Prey Chambak village narrated:

I was taught silk weaving by my mother and grandmother. I remember very well how they grew mulberry trees in the garden of our house and fed silk worms. My mother was kouncen and my father Khmer. My mother never talked about her Chinese descent.... Every August my mother celebrated saen kbal tuk [the Hungry Ghost festival in the Chinese calendar] and in April, during chingming [Ancestors Day, Chinese Memorial Day or Tomb Sweeping Day for the Chinese], she worshipped her ancestors at our family grave just outside the village. She never worshipped Khmer New Year, only Chinese New Year. I do celebrate Khmer New Year and phcum ben [a Cambodian religious festival, culminating in celebrations on the 15 th day of the tenth month in the Khmer Calendar] (Interview, December 2004). 
In many lowland rural households, one or two looms are usually placed in the shade under the house that stands on stilts or poles, a space that weavers share with their cattle, poultry and all kinds of agricultural equipment. While men attend to the rice paddies and the fields, weaving is a women's task. As a consequence of the civil war associated with the end of the Khmer Rouge regime, a large number of rural households is headed by widows or divorced women (Dongelmans et al., 2005: 27). While handloom weaving has been maintained as part of the household economy, sericulture had fallen into decay after independence, leaving the weavers dependent on imports of silk yarn from myriad of foreign countries, including Vietnam, Uzbekistan, China and Japan (Ter Horst, 2008: 144).

\section{The Wholesalers}

Among the first to resume the silk yarn trade with Chinese-owned filatures across the Vietnamese border were five female traders from Takeo and Prey Veng silk producing and trading families that trace their genealogy to the Shunde county in the Pearl River delta. These women inherited the silk trade business from their parents who had managed far-flung networks distributing raw silk from mulberry plantations in Kampot, Takeo and Prey Veng to French operated spinneries in Vietnam and to Phnom Penh and Bangkok markets. After the civil war, these women - some of whom were widowed or divorced - involved themselves in petty trade in all kinds of goods that trickled across the porous Thai and Vietnamese borders. Silk yarn and sampot were among these goods. Initially the traders acted as intermediaries in the silk yarn trade which passed through Cambodia for lack of direct linkages between Vietnam and Thailand. Gradually, however, they started to provide silk yarn to the reemerging Cambodian market. 
These five wholesalers came to control the entire silk yarn trade in Cambodia. They do so not as competitors but by operating a close-knit and far-flung Chinese business network. The common descent from southern China and the shared family background in Takeo province helped the re-establishment of business ties with middlemen from their own weaving villages in Takeo. In some cases, former Takeo weavers were sub-contracted as middlemen, with whom the wholesalers established long-term credit relationships. In the 1980, under Vietnamese control, the Cambodian government issued restricting measures on Chinese business activities that were regarded as a threat to the exclusive role of the state as a regulator and revenue collector. The silk wholesalers, however, managed to establish close patron-client relationships with high-ranking Khmer state officials. In some cases these relationships were forged through marriage. As one of the wholesalers, established in a Chinese courtyard house displaying the usual Chinese identity markers, related:

Before the war I was a merchant in Takeo province. The silk industry was only small and only rich people bought sampot in my shop. They were governors, professors and businessmen. In those days some weavers had their own mulberry gardens and reeled their own silk, but most silk yarn already came from Vietnam and China. The Chinese even had their reeling factories in Phnom Penh. Most of the Vietnamese silk yarn was redistributed to Thailand, which was a much bigger market. In the Sihanouk era my father bought silk yarn from traders in Phnom Penh, Tan Chau and Hanoi and sold it to weavers in Cambodia and Thailand. After the war was over I continued his silk business and bought silk yarn from Vietnamese traders. I knew them very well because of my father of course. For the distribution to Thailand I first 
sub-contracted Thai traders, but they cheated on me and that is why I sub-contracted Khmer traders from Poipet. Today I am still a wholesaler for some 20 middlemen, but I am also a hotel owner now.... It is true I work together with other wholesalers for the procurement of yarn. We have been working together already for twenty years. I know them very well, because they are from Takeo as well. We were all middlemen there (Interview, March 2005).

The core business of these wholesalers is the import of silk yarn, mainly from Vietnam, but also other foreign countries. The imported silk yarn is stocked up in the shops waiting to be resold to the Cambodian weaving communities and to Thai and other foreign customers. The redistribution of the raw silk is organised through networks of middlemen. To provide the silk weavers with raw material the wholesalers subcontracted some twenty middlemen each, who again sell a large part of the finished silk clothes to the same wholesalers, and a remaining bulk to retailers in the main markets of Phnom Penh (Ter Horst, 2008: 148).

\section{The Middlemen}

In colonial times French agronomists observed the essential role that middlemen been playing for peasants and weavers in the rural hinterlands, supplying them with a variety of goods (silk yarn, dye-stuff and loom materials) and services such as bulking, storing, transporting and credit supply (see Delvert, 1961). Currently, about 100 middlemen operate in the silk weaving industry, with 30 to 50 larger operators dominating the sector, providing silk yarn to some 20,000 silk weavers. In turn, these big middlemen are closely related to one 
of the five wholesalers in Phnom Penh. A survey by Dongelmans and colleagues (2005) shows that only $19 \%$ of the silk weavers can afford to pay directly for the silk yarn, which means that almost all weavers are in constant debt to their middlemen. As a result, large numbers of weavers are controlled by a few big middlemen. Their exclusive relationship with the Phnom Penh wholesalers providing a guaranteed market for their merchandise and the debt relationship with weavers who obtain silk yarn on credit propels these middlemen in a powerful position.

The close-knit texture of the silk industry comprising of co-operating wholesalers and close-knit ties between wholesalers and middlemen holds the industry in a firm grip. Hence the silk sector evolved into a closed system, which one can only enter on the basis of "trusted" social relationships. These relationships are said to be based on guanxi and entail mutual visits to each others' homes at particular festive occasions such as birthdays, marriage, funerals or special marked days of the Chinese or Khmer calendar (Ter Horst, 2008: $192 \mathrm{ff})$. These visits take on a particular meaning if the powerful wholesaler comes to the home of a middleman. This is not only a particular honour paid to the middleman, but also implies a check on their reputation as creditworthy businesspeople, as members of the local rotating credit systems, and the respect they enjoy in their community, among the weavers, and the local officialdom. An example is Mr. Mong. To win the blessings of the village leader Mr. Mong (aged 42), a middleman living in Kpam village in Takeo province, organises a bon kathen [a Buddhist festival celebrating the end of the monks' retreat] ceremony every year in October or November, depending on the Buddhist lunar calendar. This annual ceremony features the village pagoda and donations made to local Buddhist monks in return for merit. Traditionally lay people donate cotton krama [a woven cloth made of cotton, silk or a mixture, and used in manifold ways], but lately wealthy government officials and merchants have been donating money for the building of schools, irrigation 
projects or a new road. By organising a bon kathen ceremony Mr. Mong builds on his longterm relationships with his wholesaler. He may ask her to donate a great sum of money on behalf of a local road or another charity project. In this way Mr. Mong can present himself symbolically as a powerful Chinese merchant with good connections and impress the local officialdom.

Middlemen are most literally "brokers" between two "worlds": the rural household economies that are defined as "typically" Khmer and the urban lifestyles of the "Chinese" business class. Their business success largely depends on their competence of fitting in with both worlds. Middlemen encountered during fieldwork developed a multiple lifestyle that made them acceptable both as Khmer villagers and as urban business people. As Mr. Mong explained: "If I am in my shop in Takeo I feel Khmer. Then I wear a sarong and I walk around on bare feet. But when I am in Phnom Penh I always wear pants and white trousers. The wholesalers like that (Interview, November 2004).

As descendents of the weaver class, the middlemen were socialised as ethnic Khmer. Moving into the role of intermediary, many ambitious middlemen started to copy the lifestyle of the wholesalers and built a new courtyard house outside the village adorned with red lampions, good-luck stickers, and a Chinese shrine and displaying Chinese newspapers, a Chinese calendar and Chinese brand goods. They came to dress in Chinese style when travelling to the city and celebrate Chinese New Year. The "Chinese" lifestyle radiated symbols of business success and power, while the middlemen lacked knowledge of the Chinese language, could not read the Chinese newspapers and calendars and also had no clue who the deities on their shrines were, and what position they had in the Chinese pantheon of gods. As a silk weaver remarked: "No, of course they are not Chinese; they were weavers just like me and know nothing about the Chinese culture. But now they are middlemen, they must be cen" (Interview, September 2004). 


\section{Retailers and Markets}

As in other Southeast Asian countries, markets play an important role in the lives of the people of Phnom Penh. Since 2001 the number of retail outlets in Phnom Penh has almost doubled due to the growth of the urban economy (Ter Horst, 2008: 152). Very much in demand among tourists and other foreign visitors is Psah Toul Tom Poung (its English name, Russian Market, is not a literal translation). At the Russian Market some 50 vendors offer a wide variety of silk handicrafts from Laos and Thailand to these tourist groups, but no sampot can be found. The Central Market (Psah Thmei) attracts mainly Western expatriates and tourists because of its architectural beauty and its prominent position in all kinds of travel guides. At the entrance of the Central Market some 40 silk vendors try to draw tourists to their stalls piled up with machine-made silk handicrafts and table clothes from Thailand, Laos and Burma, and, to a lesser extent, with sampot hol. Most of the silk vendors at the Central Market are former weavers from Takeo and Prey Veng provinces who migrated to Phnom Penh in the 1990s.

Youn Malis is a typical example. She is a middle-aged silk hawker at the Central Market, and a former weaver from Prek Changkran village in Kampong Cham. She is of Sino-Khmer descent. Just like her own mother, she got married to a Khmer farmer from the same village. In the 1980s the couple moved to Phnom Penh, and in 1992 Youn Malis sold two hectares of land in order to buy a stall for 200 dollars at the Central Market and a stock of sampot hol to get into the business. Her husband found a job as a state official at the tax department. Her younger daughter occasionally assists her in the shop. Youn Malis has a sister who in the early 1980s was accepted to the United States as a refugee. This sister has a good job as a nurse and visits Phnom Penh once a year. She usually buys sampot from Youn 
Malis' shop to resell to other Cambodians in the United States. Like many Cambodians of mixed descent, Youn Malis observes both Chinese and Khmer festive days. During saen kbal tuk, Youn Malis burns paper money in the Chinese fashion - a habit, she explained, that she adopted from her parents. This is as far as her affinity with her Chinese roots stretches. She shows as much devotion to all kinds of Khmer ceremonies such as phcum ben, Khmer New Year, the King's birthday and the water festival.

In summary, the contemporary Cambodian silk industry shows a pyramidal and ethnicised structure in which all commercial positions - wholesaler, middleman trader and retailer - associate themselves with varying degrees of Chinese identity. Five female wholesalers are at the top of this pyramid controlling the cross-border silk yarn trade with Vietnamese filatures and - through an extended network of middlemen and retailers $-\mathrm{a}$ substantial portion of the trade in finished silk products. The five silk wholesalers subdivide the silk market among them in an oligarchic arrangement maintaining almost exclusive ties with about 100 middlemen and - through them absorb about 20,000 weavers into this closed system. The wholesalers publicly display their Chinese identity as expressed by the decoration of their homes that double as warehouses, their observation of Chinese holidays and, most of all, their guanxi-based business operations. Middlemen exude a flexible approach to ethnic self-presentations varying between Khmer and Chinese styles according to the requirements of the situation. The female market retailers observe a mix of both Chinese and Khmer cultural practices reflecting their upbringing as a Sino-Khmer. The weavers residing in rural areas - many of whom are of mixed descent - used to keep silent about their partial Chinese background, a legacy of the Pol Pot era when many people of Chinese and mixed descent concealed their non-Khmer background in attempt to escape Khmer Rouge atrocities. They blend into Khmer village life by wearing Khmer attire and assume a rural lifestyle. In the following section this ethnicised structure of the silk industry will be analysed 
in terms of the institutional legacies in which current Chinese-Khmer relations are embedded and which contribute to the institutionalisation of Chineseness in contemporary Cambodian society.

\section{INSTITUTIONAL LEGACIES OF THE CHINESE}

The Chinese dominance in commercial positions in the Cambodian economy is embedded in the pre-colonial legacies of early Chinese migration and settlement, as has been shown in a previous section. Scholars who studied the history of the Chinese in Cambodia speak of "assimilation" through intermarriage with Khmer people (Willmott, 1967: 28) and "cultural tolerance and mutual exchange" (Edwards, 2003: 8) when describing the position of the Chinese in the Cambodian kingdom before colonialism.

Conversely, the colonial state created a legacy that facilitated the institutionalisation of ethnic differences. By organising the economy along ethnic lines and carving out specific economic niches for different ethnic groups, the French laid the groundwork for a persistent ethnic divide. Under the French, Cambodian citizenship became an exclusive attribute of Khmer people; all Chinese (also those born in Cambodia) and Sino-Khmer were classified as "Chinese" (Willmott, 1967: 75-76). Conversely, the Khmer were celebrated as the authentic creators of the great Angkor kingdom, toiling the soil in subsistence fashion and paying tribute to their king. The Chinese were branded as economically necessary but culturally polluting aliens useful only in - and therefore confined to - the commercial trades (Edwards, 2007: 140). This was the onset of an imagined division of labour in the silk industry where only Khmer people were deemed capable of producing authentic silk that constituted the appropriate attire at Khmer festivals and the court under Khmer dress code. Therefore, and in order to avoid the colonial authorities' questioning the ownership of their plots, the Sino- 
Khmer weavers silenced their partial Chinese descent and melted into the Khmer rural life. In the silk industry, the Chinese were deemed to act - in their classical role of traders and middlemen - only as distributors, not as producers, of the silk-woven products across the kingdom and beyond.

When Cambodia became independent in 1953, Chinese people could become Khmer under a new naturalisation law, but the colonial legacy of ethnic divisions survived. The Chinese had secured their economic wealth and influence despite inhospitable colonial policies (Willmott, 1998: 146). In the towns their economic activities were rather diverse and far-flung; in the rural areas - even in the remotest villages - all commercial sectors were united in one single person, the village shopkeeper, who acted as trader and retailer as much as middleman and moneylender. Through the shopkeepers the silk weavers obtained the silk yarn traded across the border and gave their finished silk fabrics in commission to be sold to the wholesaler in town. However, decolonisation did not change the alienation of the Chinese middle class that set off under colonialism. Fuelled by the Khmer nationalist movement that elaborated the French-induced images of Angkor grandeur and Khmer purity and declared commercial activities alien to authentic Khmer society, the Chinese became increasingly disembedded from this society and were pushed further into the role of outsiders. As Cambodia was drawn into the Cold War, the position of the ethnic Chinese became even more jeopardised forcing expressions of Chinese culture and language virtually underground (Edwards, 2007: 200; Willmott, 1998: 147). Finally, images of pure Khmerness in terms of a land-toiling peasantry exempt from the repression by the commercial class were at the root of the revolution leading to the establishment of the brutal Khmer Rouge regime. Chinese were either forced to "become Khmer" in terms of housing, dress, language and food (assuming a rural lifestyle and disposing of tokens of their Chinese descent), or eliminated as representatives of the much hated capitalist class (Edwards, 2007: 201-2). 
Under Vietnamese occupation, the post-colonial legacy of anti-Chinese policies and sentiments merged with cold-war rhetoric (Edwards, 2003: 30). In an absurd denial of Chinese suffering, the ethnic Chinese were accused of having backed the Khmer Rouge, an accusation that was to legitimise repressive measures against Chinese businesspeople (Gottesman, 2003: 183). The peddling careers of the five Sino-Khmer women operating in the Cambodian province and border lands in the 1980s, the women who rose to great wealth and power as silk wholesalers in the 1990s, may be illustrative of the failure of such measures to change the dependence on private Chinese enterprises in the Cambodian economy (Gottesman, 2003: 186). However, these measures enforced the silencing of Chinese identity that has commenced in the 1960s. It was only after the 1991 Paris Accords and the withdrawal of Vietnamese forces that Chinese festivals were allowed again, the Association of Chinese Nationals in Cambodia (ACNC) was established and Chinese New Year was celebrated in public (Willmott, 1998: 148).

Interestingly, the three decades of oppression of Chinese population and the virtual disappearance of their culture from public life have enforced the institutionalisation of Chinese identity as a model of and for business and commercial conduct. This enforcement occurred through the opposite of Chinese presence: the very invisibility of the Chinese in public life became closely associated with the decline and - during the Pol Pot regime - total eclipse of the Cambodian economy.

The end of conflict left Cambodia with an economy that relies on foreign assistance. As critical observers argue, massive amounts of aid turned out counter-productive for development as it weakened institutional capacity (Ear, 2007). Domestic companies do not participate much in terms of investments and exports, the more so as the government falls short of providing effective law-enforcement, a reliable system of state revenue collection, and overall trust in the state apparatus (Hughes, 2002; Kent, 2006). Conversely, due to Prime 
Minister Hun Sen's pragmatic, capitalist-oriented view of rebuilding the country, there is an almost unlimited license for private sector initiatives. Among the initiators of business ventures are people of Chinese descent who survived the Khmer Rouge atrocities by hiding their background and blending into Khmer rural life while- after the 1979 defeat of the regime - eventually resuming their commercial activities and strategically exploiting what was left of their network (Gottesman, 2004: 175-6). The re-emergence of Chinese businesses in Cambodia exemplifies that it is not ethnicity per se or the inherent Chinese character of capitalism that spawned private sector initiatives. Instead, the institutional legacies of family linkages and common decent, reciprocity and guanxi, networks and patronage relations provided flexibility and resilience in the opaque and insecure environment of the post-conflict economy. In the silk sector, among those who were able to draw on some measure of "institutional thickness" were the widowed Sino-Khmer female peasants who took to their hand-looms to earn a living and the descendants of former middlemen and traders who resumed pushing goods across the closed but porous Cambodian borders. Other commercial initiatives originate through remittances and direct investments among Sino-Cambodians exiles and former refugees - residing abroad (Dahles and Ter Horst, 2006). In particular, prominent Chinese families have re-established themselves as the driving force of the economy. Some of these families have returned from exile and many enjoy good connections - sometimes through carefully arranged marriages - with people in (powerful) government positions (Slocomb, 2006). In the silk industry, the key figures in commercial positions often maintain patronage relations extending into government circles and foreign countries. Many wholesalers, middlemen and even market traders are either married with or related to government officials. At the same time, most wholesalers and many market traders benefit from connections with relatives residing in Western countries who provide access to foreign markets. The post-conflict legacy is one of institutional void when it comes to state 
regulations and rule of law. However, it offers myriad opportunities for those who have access to networks that comprise of patronage relations and transnational linkages.

\section{CONCLUSION}

This article shows how multilayered legacies contributed to the establishment of the cen - Chinese and/or trader - as an economic institution in Cambodian society. Throughout history, the involvement of people of Chinese descent with Cambodian society created institutional legacies that exerted opportunities and restraints, benefits and threats to the Chinese in Cambodia. Their persistent dominance in commercial life is a pre-colonial legacy created in a situation of economic symbiosis with Khmer peasant society. The complementary division of economic tasks between Khmer farmers and Chinese traders was socially embedded in Cambodian society when the French colonisers resumed to measures that institutionalised this division. With this institutionalisation emerged an ethnic divide that gained a cultural dimension through the rhetoric of Khmer purity and Chinese commercialism (Edwards, 2007). Through the intervention of the colonial state, marking the advent of modernity, the fluidity of ethnic categories characteristic of the Khmer kingdom changed into rigid divisions that were disembedded from the context of local society. The occupational constraints placed on the Chinese marked the fusion of commercial activities and Chinese identity into one single concept, the cen. Not only were all Chinese viewed as being "naturally" involved in commercial activities, but also were all commercial activities seen as "essentially" Chinese. While culturalist perspectives on Chinese capitalism reflect such essentialism, centuries of Chinese presence and intermarriage with Khmer people had created a society in which clear ethnic distinctions were contrived and any attempt at imposing ethnic divisions were essentialist in nature and represented an act of power politics. These power 
politics towards the Chinese were continued after independence, an era that was coined by Cold War involvement. Merging with the post-colonial legacy, the cold-war rhetoric is one of silencing and hiding expressions of Chinese identity and melting into the colonial fiction of authentic Khmer society. The institutional void in Cambodia's political economy after the Khmer Rouge offered economic opportunities to the survivors of the regime. Lacking models for entrepreneurial behaviour other than the institutional legacies of the past, the cen provided formats for proper conduct in commercial activities in post-conflict Cambodia, such as alleged Chinese dress codes, home and shop decorations, and the observance of Chinese holidays, gift giving and money lending activities. Vice versa, there are conventional forms of conduct for those who engage in rural lives and make a living of farming: that is, Khmer identity. People involving in either commercial ventures or farming activities are expected to display such patterns of conduct and self-presentation irrespective of their ethnic background. While ethnicity seems to have become disembedded from its social meaning in the ethnically mixed Cambodian society, it has gained importance in the economic realm where occupational identities have become institutionalised according to essentialised ethnic formats derived from the legacies of the past.

It was modernity that was the harbinger of "Chineseness"- or ethnic Chinese identity among Chinese migrants living scattered across Southeast Asia. With the rise of the modern society in the shape of the colonial state, the culturally diverse population of Southeast Asian kingdoms became classified in separate ethnic groups with majority and minority statuses affixed and well-policed boundaries established. In the late capitalist era, characterised by a global economy consisting of far-flung but interconnected and rapidly changing sites of doing business, the principles of ethnic Chinese business networks turn out to be more than just a trope. The "celebratory narratives of Chinese business success" referred to be Nonini and Ong (1997: 21) have turned into a viable model for business activities that require flexibility 
and resilience in opaque and insecure environments - emerging economies, fragile states or global markets. Hence, due to their institutional legacies, in particular the legacy of commercial intermediary in insecure environments, ethnic Chinese business itself is turning into an institution. 


\section{REFERENCES}

Arnold, D. and Toh Han Shih (2010) "A Fair Model of Globalisation? Labour and Global

Production in Cambodia," Journal of Contemporary Asia, 40, 3, pp. 401-24.

Chan Kwok Bun (2000) "State, Economy and Culture: Reflections on the Chinese Business Networks," in Chan Kwok Bun (ed.), Chinese Business Networks: State, Economy and Culture, Singapore: Prentice Hall, pp. 1-13.

Chan Kwok Bun and Tong Chee Kiong (2000) "Singaporean Chinese Doing Business in China," in Chan Kwok Bun (ed.), Chinese Business Networks: State, Economy and Culture, Singapore: Prentice Hall, pp. 71-85.

Chang, I. (2003) The Chinese in America. A Narrative History. New York: Penguin Group.

Cohen, R. (1997) Global Diasporas. An Introduction, London: UCL Press.

Crawford, B. and A. Lijphart (1997) “Old Legacies, New Institutions: Explaining Political and Economic Trajectories in Post-Communist Regimes," Global, Area, and International Archive (GAIA), http://escholarship.org/uc/item/)ds5j5ss (downloaded 16 January 2010).

Dahles, H. and J. Ter Horst (2006) "Weaving into Cambodia: negotiated ethnicity in the (post)colonial silk industry," in L. Ollier and T. Winter (eds), Expressions of Cambodia. The politics of tradition, identity, and change, London: Routledge, pp. 119-32. 
Dahles, H. and E. Zwart (2003) “Tourism and Silk Trade in Post Civil War Cambodia," Pacific Tourism Review, 7, 3-4, pp. 143-57.

Deloche de Campocasso, M. (1923) Le Cambodge Economique. Hanoi: impremerie d'extreme-orient.

Delvert, J. (1961) Le paysan Cambodgien. Paris/La Haye: Mouton.

Dongelmans, B., B. Seng and J. Ter Horst (2005) Silk Weaving in Cambodia. A national census, Phnom Penh: Centre For Advanced Studies.

Ear, S. (2007) "The Political Economy of Aid and Governance in Cambodia," Asian Journal of Political Science 15, 1, pp. 68-96.

Edwards, P. (2001) “Restyling Colonial Cambodia (1860-1954): French Dressing, Indigenous Customs and National Costume," Fashion Theory, 5,4, pp. 389-416.

Edwards, P. (2003) The Ethnic Chinese in Cambodia, Phnom Penh: Center For Advanced Studies.

Edwards, P. (2007) Cambodge. The Cultivation of a Nation, 1860-1945, Honolulu: University of Hawai'i Press.

Edwards, P. (2009) "Ethnic Chinese in Cambodia," in Center for Advanced Study (eds), Ethnic Groups in Cambodia, Phnom Penh: Center for Advanced Study, pp. 174-233. 
Forest, A. (1980) Le Cambodge et la Colonisation Francaise, Paris: L'Harmattan.

Frederico, G. (1997) An economic history of the silk industry, 1830-1930, Cambridge:

Cambridge University Press.

Fukuyama, F. (1995) Trust: The Social Virtues and the Creation of Prosperity, New York: Free Press.

Giddens, A. (1990) The Consequences of Modernity, Cambridge: Polity Press.

Gomez, E. (1999) Chinese Business in Malaysia: Accumulation, Accommodation and Ascendance, Richmond: Curzon Press.

Gomez, E. (ed.) (2002) Political business in East Asia, London/New York: Routledge.

Gomez, E. and M. Hsiao (2004) "Introduction: Chinese Business Research in Southeast Asia," in E. Gomez and M. Hsiao, Chinese business in Southeast Asia. Contesting cultural explanations, researching entrepreneurship, London and New York: Routledge, pp. 1-37.

Gottesman, E. (2003) Cambodia After the Khmer Rouge: Inside the Politics of Nation Building, New Haven and London: Yale University Press.

Granovetter, M. (1985) "Economic Action and Social Structure: The Problem of Embeddedness," The American Journal of Sociology, 91, 3, pp. 481- 510. 
Green, G. (2003) Traditional Textiles of Cambodia. Cultural Threads and Material Heritage, Bangkok: River Books.

Green, G. (2004) “Textiles at the Khmer Court, Angkor. Origins, Innovations and Continuities," in J. Purananda (ed.), Through the Thread of Times, Bangkok: River Books, pp. 10-25.

Hamilton G. (ed.) (1996) Asian Business Networks, Berlin: Walter de Gruyter.

Hamilton, G. (2000) "Reciprocity and Control: The Organization of Chinese Family-Owned Conglomerates", in Yeung, H. and K. Olds (eds), Globalization of Chinese Business Firms. Houndmills, Basingstoke: Macmillan Press, pp. 55-74.

Hamilton, G. (2006) Commerce and Capitalism in Chinese Societies, London and New York: Routledge.

Hammersley, M. and P. Atkinson (1995) Ethnography: principles in practice, 3rd edition, London and New York: Routledge.

Hatch, M. J. and M. Schultz (eds) (2004) Organizational Identity. A Reader, Oxford: Oxford University Press.

Henry, Y. (1932) Economique Agricole de L'Indochine. Hanoi: impremerie d'extreme-orient. 
Hodgson, G. (2006) “What Are Institutions?”, Journal of Economic Issues, XL, 1, pp. 1-25.

Howard, M. (1999) "Ikat Weaving and Ethnic Identity Among Ethnic Minorities in Vietnam," in G. Hainsworth. Globalization And The Asian Economic Crisis. Indigenous Responses, Coping Strategies, and Governance Reform in Southeast Asia, Vancouver: Center for Southeast Asia Research, pp. 127-42.

Hughes, C. (2002) "Parties, Protest and Pluralism in Cambodia," Democratization, 9, 3, pp. 165-86.

Igout, M. (1993) Phnom Penh Then and Now, Bangkok: White Lotus.

Ishii, Y. (1998) The Junk Trade from Southeast Asia. Translations from the Tosen Fusetsugaki, 1674-1723, Singapore: Institute of Southeast Asian Studies.

Jesudason, J. (1989) Ethnicity and the Economy: The States, Chinese Business, and Multinationals in Malaysia, Oxford University Press, Singapore.

Kent, A. (2006) "Rifts and repair in the Cambodian moral landscape". NIAS nytt. Asia Insights. Theme: Justice in Cambodia, 3, pp. 4-5.

Kiernan, B. (1986) 'Kampuchea's Ethnic Chinese Under Pol Pot: A Case of Systematic Social Discrimination,” Journal of Contemporary Asia, 16, 1, pp. 18-29. 
King, V. and W. Wilder (2003) The Modern Anthropology of South-East Asia. An Introduction, London: RoutledgeCurzon.

Kotkin, J. (1993) Tribes: How Race, Religion, and Identity Determine Success in the New Global Economy, New York: Random House.

Kuhn, P. (2006) Chinese Among Others: Emigration in Modern Times, Singapore: National University of Singapore Press.

Larsen, J.L. (1979) The Dyers'Art: Ikat, Batik, Plangi. New York: Van Nostrand Reinhold.

Marks, S. (2010) “Cambodia Slowly Reweaves Its Silk Industry,” New York Times, September 22, 2010. http://www.nytimes.com/2010/09/23/fashion/23iht-rsilk.html.

McVey, R. (ed.) (1992) Southeast Asian Capitalists, Ithaca, NY: Cornell University, Studies on Southeast Asia.

Menkhoff, T. and S. Gerke, (2004) “Asia's Transformation and the Role of the Ethnic Chinese," in T. Menkhoff and S. Gerke (eds), Chinese Entrepreneurship and Asian Business Networks, Routledge, London, New York, pp. 3-19.

Miles, S. (2006) "Expanding the Cantonese Diaspora: Sojourners and Settlers in the West River Basin," Journal of Chinese Overseas, 2, 2, pp. 220-47. 
Morgan, G. and S. Quack (2005) "Institutional legacies and Firm Dynamics: The Growth and Internationalization of British and German Law Firms," Organization Studies 26,12, pp. 1765-86.

Muan, I and L. Daravuth (eds) (2003) Seams of Change. Clothing and the Care of The Self in Late 19th and 20th Century Cambodia. Phnom Penh: Reyum Publishing.

Nonini, D. and A. Ong (1997) "Introduction: Chinese Transnationalism as an Alternative Modernity," in A. Ong and D. Nonini (eds), Ungrounded Empires: The Cultural Logics of Modern Chinese Transnationalism, New York: Routledge, pp. 3-33.

Pujebet, V and A. Peyre (2001) “Options for establishing a full production and marketing chain for silk products in Southern Cambodia”. Draft mission report presented to Support Programme for the Agricultural Sector in Cambodia. Phnom Penh: October 2001.

Rasiah, R. (2009) "Can Garment Exports from Cambodia, Laos and Burma be Sustained?" Journal of Contemporary Asia, 39, 4, pp. 619-37.

Redding, S.(1990) The Spirit of Chinese Capitalism, New York: Walter de Gruyter.

Reid, A. (1993) Southeast Asia in the Age of Commerce 1450-1680. Volume Two: Expansion and Crisis, Bangkok: Silkworm Books. 
Reid, A. (ed.) (1996) Sojourners and Settlers: Histories of Southeast Asia and the Chinese, St. Leonard: Allen and Unwin.

Robequain, C. (1944) The Economic Development of French Indo-China. London: Oxford University Press.

Scott, W. (2001) Institutions and Organization, 2nd Edition, New Delhi: Sage Publications.

Searle, J. (1995) “What Is an Institution?” Journal of Institutional Economics 1, 1, pp. 1-22.

Slocomb, M. (2006) "The Nature and Role of Ideology in the Modern Cambodian State," Journal of Southeast Asian Studies, 37, 3, pp. 375-95.

So, A. (1986) The South China Silk District. Local Historical Transformation and WorldSystem Theory, Albany. State University of New York Press.

Stuart-Fox, M. (2003) A short history of China and Southeast Asia. Tribute, trade and influence. Sydney: Allen and Unwin.

Suryadinata, L. (1997) "Ethnic Chinese in Southeast Asia: Overseas Chinese, Chinese Overseas or Southeast Asians?"in L. Suryadinata (ed.) Ethnic Chinese as Southeast Asians, Singapore: Institute of Southeast Asian Studies, pp. 1-25. 
Tan Chia-Zhi and H. Yeung 2000, “The Internationalization of Singaporean Firms into China: Entry Modes and Investment Strategies,” in H. Yeung and K. Olds (eds), Globalization of Chinese Business Firms, Houndmills: Macmillan, pp. 220-43.

Ter Horst, J. 2008, "Weaving Into Cambodia: Trade and Identity Politics in the (post)Colonial Cambodian Silk Weaving Industry," Unpublished PhD dissertation, VU University, Amsterdam.

Tomlinson, J. (2003) "Globalization and Cultural Identity," in D. Held and A. McGrew, The Global Transformations Reader: an introduction to the globalization debate, Cambridge: Polity Press, pp. 269-77.

Vickery, M. (2004) "Cambodia and its Neighbors in the 15th Century," Singapore: Asia Research Institute, Working Paper Series 27.

Wee, V. and Chan Yuk Wah (2006) "Ethnicity and capital: Changing relations between China and Southeast Asia," Journal of Contemporary Asia, 36, 3, pp. 328-49.

Wee, V., M. Jacobsen and Wong Tiong Chong (2006) "Positioning Strategies of Southeast Asian Chinese Entrepreneurs," Journal of Contemporary Asia, 36, 3, pp. 364-84.

Weidenbaum, M. and S. Hughes (1996) The Bamboo Network: How Expatriate Chinese Entrepreneurs Are Creating a New Economic Superpower in Asia, New York: The Free Press. 
Willmott, W. (1967) The Chinese in Cambodia, Vancouver: University of British Columbia.

Willmott, W. (1970) The Political Structure of the Chinese Community in Cambodia.

University of London: The Athlone Press, New York: Humanities Press.

Willmott, W. (1998) "Cambodia," in L. Pan, The Encyclopedia of the Chinese Overseas, Randwick: Archipelago Press, pp. 144-50.

Yeung, H. and K. Olds (2000) "Globalizing Chinese Business Firms: Where Are They Coming From, Where Are They Heading?" in Globalization of Chinese Business Firms, Yeung, H. and K. Olds (eds), Houndmills: Macmillan Press, pp. 1-30.

Ying Fan (2002), "Questioning Guanxi: Definition, Classification and Implications", International Business Review, 11, 5, pp. 543-61.

Zukin, S. and P. DiMaggio (1990) Structures of Capital: The Social Organization of the Economy, New York: Cambridge University Press. 


\section{NOTES}

${ }^{1}$ The term cen denotes second and third generation Chinese in Cambodia whose lineage is Chinese. Synonyms are kouncen (children of Chinese) or kounciwcen (grandchildren of Chinese) (Edwards, 2009: 176).

${ }^{2}$ Guanxi translates as "good connections," personalised networks of influence or social capital (Ying, 2002). 